\title{
Effect of different culture media on growth of Chlorella sorokiniana and the influence of microalgal effluents on the germination of lettuce seeds
}

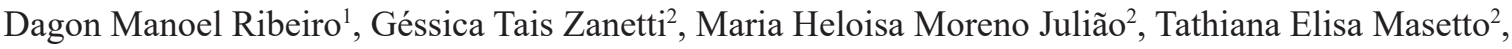 \\ Jane Mary Lafayette Neves Gelinski ${ }^{3}$, Gustavo Graciano Fonseca ${ }^{1,3, *}$ \\ ${ }^{1}$ Laboratory of Bioengineering, Faculty of Biological and Environmental Sciences, Federal University of Grande Dourados, Dourados - MS, Brazil. \\ ${ }^{2}$ Faculty of Agricultural Sciences, Federal University of Grande Dourados, Dourados - MS, Brazil. \\ ${ }^{3}$ Center of Biotechnology, Postgraduate Program in Science and Biotechnology, the University of West of Santa Catarina, Videira - SC, Brazil.
}

\begin{tabular}{|c|c|}
\hline ARTICLE INFO & ABSTRACT \\
\hline Article history: & Increased use of microalgae as food additives, biofuels, pharmaceuticals and in waste treatment increases \\
\hline Received on: June 07, 2018 & effluent production. The aim of this work was to evaluate the effect of different culture media on the growth of \\
\hline Accepted on: July 08,2018 & Chlorella sorokiniana and the influence of the cultural refuse on seed germination of lettuce (Lactuca sativa). \\
\hline Available online: January 20, 2018 & $\begin{array}{l}\text { The microalga was grown in different media for } 27 \text { days. The maximum specific growth rate }\left(\mu_{\max }\right) \text { during } \\
\text { mixotrophic growth phase was obtained in the novel medium composed of } 50 \% \text { NPK medium and } 50 \% \text { Bold }\end{array}$ \\
\hline $\begin{array}{l}\text { Key words: Growth parameters, } \\
\text { Organic fertilizers, Horticulture, } \\
\text { Plant development, Waste. }\end{array}$ & $\begin{array}{l}\text { Basal medium supplemented with glucose }\left(1 \mathrm{~g} \mathrm{~L}^{-1}\right) \text {. Cell proliferation in Bold Basal and NPK media presented } \\
\text { a very close } \mu_{\max } \text { values, indicating that NPK may be a good option for low-cost microalgal production. The } \\
\text { effluents from the microalgal culture failed to induce any marked variation in the germination of lettuce seeds. } \\
\text { This clearly shows that the microalgal effluent does not cause any toxicity to germinate lettuce seeds. Thus } C \text {. } \\
\text { sorokiniana cultivation combined with horticulture can be utilized as a feasible productive integrated system. }\end{array}$ \\
\hline
\end{tabular}

\section{INTRODUCTION}

Research on the cultivation of microalgae has been growing over the years and advances are still being made in various segments of microalgae production, mainly for the understanding of microalgae physiology, photobioreactors' evaluation, biomass recovery and product development and applications [1,2].

Microalgae are a potential raw material for various sectors of industry as food products, biofuels, organic products, bioplastics, pigments, cosmetics and pharmaceuticals [3-8]. On the other hand, sustainable microalgal production has several technological and economic obstacles that must be overcome. One of them is the choice of an effective strategy for the recovery or harvesting of microalgae biomass from their culture medium [9], which requires the development of an energetically favorable, environmentally friendly and economically viable process [10], aggravated by the low cell concentration [11].

\section{${ }^{*}$ Corresponding Author}

Gustavo Graciano Fonseca, Federal University of Grande Dourados, Faculty of Biological and Environmental Sciences, CEP 79.804-970, Dourados - MS, Brazil.E-mail: ggf@ufgd.edu.br
Thickening methods, e.g. gravimetric sedimentation, flotation, flocculation, lead to the increase of the microalgae concentration and the reduction the volume to be processed, contributing to energetic savings [12]. However, after applying some thickening method, there is still cells and water that can be drained through higher-cost drainage methods or simply utilized in other processes.

In this sense, with improving technologies and applications of microalgal production, the concern with the fate of the effluents of this production also grows. Each culture can produce different extracellular compounds, metabolites, and phytohormones that may or may not be beneficial to other organisms.

Lettuce (Lactuca sativa L.) is one of the main vegetables cultivated in Brazil due to its low cost of production, low susceptibility to pests and diseases, and safe marketing. Thus, lettuce plays an important role in small-scale farming. The lettuce seeds are widely used in toxicity research due to its quick and easy-to-evaluate responses [13].

The use of chemical synthetic fertilizers can lead to nutritional imbalances in plants, contaminate the soil and groundwater, as well as weaken the plants [14]. To reduce this effect in recent years, interest in organic farming is increasing [15]. The use of high-quality organic fertilizers is a low-cost strategy that tends to contribute to a higher 
productivity in vegetative development and to improve the chemical, physical and biological characteristics of the soil. This enables the production of sustainable, safe, and nutrient-rich fruits and vegetables $[14,16]$.

Algal biomass contains macronutrients as well as micronutrients, some plant growth regulators, polyamines, natural enzymes, carbohydrates, proteins and vitamins implemented for improving soil characteristics that favor the nutritional status of plants in terms of vegetative growth and yield [15]. In addition, studies have reported the synthesis of auxins, cytokinins, gibberellins, brassinosteroids, amino acids and polypeptides by microalgae which are essential for the development of plants [17-19].

The use of microalgae for value addition, together with their use as organic fertilizers or as soil conditioners has become a promising economic market of these microalgae in biotechnological applications [20]. Thus, the aim of this study was to evaluate the effect of different growth media on microalgal growth and the influence of microalgal residual water on the germination of lettuce seeds.

\section{MATERIALS AND METHODS}

\subsection{Microalgae cultivation}

The microalga utilized in the experiments was $C$. sorokiniana CTT 7727 from the André Tosselo Foundation, provided by the Center for Biodiversity Research of the State University of Mato Grosso do Sul, Brazil.

Four different culture media were used for culturing microalgae. These included: the Bold Basal medium [21], the nitrogenated medium [22], the NPK medium, prepared by the dilution of $1 \mathrm{~g}$ of the chemical fertilizer N:P:K (20:5:20) for each $1 \mathrm{~L}$ of distilled water [23] and the mixed medium. The mixed medium was composed of $50 \%$ Bold Basal, $50 \%$ NPK plus $1 \mathrm{~g} \mathrm{~L}^{-1}$ glucose. All media components were sterilized by autoclaving at $121^{\circ} \mathrm{C}$ for $15 \mathrm{~min}$.

The pre-cultures were prepared by transferring $1 \mathrm{~mL}$ microalgal stock culture to $50 \mathrm{~mL}$ Erlenmeyer flasks containing $25 \mathrm{~mL}$ of media, for each culture media described above. After inoculation, flasks were maintained in BOD equipped with orbital rotatory stirrer and photoperiod (MA 415 Marconi) $\left(25 \pm 0.5^{\circ} \mathrm{C}, 200 \mathrm{rpm}, 8 \mathrm{Klux}\right)$ with photoperiod cycles of $12 \mathrm{~h}$ light/12 h dark for 7 days.

Cultivations were performed in triplicate in $250 \mathrm{~mL}$ in Erlenmeyer flasks, with $200 \mathrm{~mL}$ working volume and started by adding a certain volume of the pre-culture so that the initial cell concentration in the flask was $0.062 \pm 0.003$ absorbance units at $670 \mathrm{~nm}\left(\mathrm{OD}_{670 \mathrm{~nm}}\right)$. The main cultivation conditions during the 27 days were the same as the precultures. The experiments were performed in triplicate and the analysis of absorbance in duplicate.

The absorbance was read on a microplate reader (Biochrom model Anthos Zenyth 200rt) at the wavelength of $670 \mathrm{~nm}$ in $24 \mathrm{~h}$ time intervals. The exponential growth phase was identified as the linear region on an $\ln \mathrm{ABS}_{670}$ vs. time plot for batch cultivation data. The maximum specific growth rate $\left(\mu_{\max }\right)$ was determined as the slope of this linear region (Equation 1). The doubling time (DT) was calculated by the quotient of the $\ln (2)$ by the $\mu_{\max }$. The maximum biomass concentration was indicated by the maximum $\mathrm{ABS}_{670}$ observed in each experiment [24]. The measured absorbance was converted to cell concentration $(\mathrm{X})$ using a linear relation (optical density units per cells per $\mathrm{mL}$ ) thus obtaining a conversion factor. Maximal cell productivity $\left(P_{x}\right)$ was calculated by the quotient of the difference between maximal cell concentration $\left(X_{m}\right)$ and initial cell concentration $\left(X_{i}\right)$ by the time to reach maximal cell content $(t)$ (Equation 2).

$$
\begin{aligned}
\mu_{\max } & =\frac{1}{X} \frac{d X}{d t} \\
P_{X} & =\frac{X_{m}-X_{i}}{t}
\end{aligned}
$$

\subsection{Seed Germination Test}

The seed germination tests were carried out using the 27 days old media (Bold Basal, nitrogenated, NPK, mixed media) in which $C$. sorokiniana were cultured hereafter referred to as effluent.

Three other conditions were also evaluated either by concentrating or diluting the cultured Bold Basal medium, in order to compare the same medium effluent with different concentrations of microalgae (2.7 $\times 10^{7}, 1.23 \times 10^{7}$ and $0.15 \times 10^{7}$ cells $\mathrm{mL}^{-1}$ ) grew in the same condition described in the previous section. The microalgal cell concentrations were prepared by centrifuging the cultured Bold Basal medium on a bench centrifuge $\left(17,609 \times \mathrm{g}, 5 \mathrm{~min} ., 4^{\circ} \mathrm{C}\right)$ to achieve a cell density of $2.7 \times 10^{7}$ and $1.23 \times 10^{7}$ cells $\mathrm{mL}^{-1}$ or by diluting with cultured Bold Basal media, free of cells by centrifugation, to achieve $0.15 \times 10^{7}$ cells $\mathrm{mL}^{-1}$. Concentrations were determined by microalgal cell counting using a Neubauer chamber. The supernatants after centrifugation (effluents) were utilized after sterilization $\left(121^{\circ} \mathrm{C}, 15 \mathrm{~min}\right)$ in an autoclave.

Seed's treatment and germination tests were performed according to recommendations previously described [25]. It was evaluated four replicates of 25 seeds of lettuce (cv. Lucy Brown) seeded in sterilized Petri plates (90 mm diameter) containing two sheets of filter paper moistened with the different effluent and microalgal cell concentrations. Water was utilized as a control. Seeded plates were incubated in BOD (MA 415 Marconi) at $25 \pm 1^{\circ} \mathrm{C}$ under the white fluorescent light in 12 $\mathrm{h} / 12 \mathrm{~h}$ photoperiod. The germination percentage was calculated from the number of normal seedlings developed over a period of 10 days. The dry mass was obtained by drying the germinated seedlings at $60^{\circ} \mathrm{C}$ in circulation oven until constant weight and calculated by the average of the weighing of the germinated seedlings for each treatment [25].

The experiment was conducted in a completely randomized design and the data were subjected to the Analysis of Variance (ANOVA). When ANOVA was significant the means were separated using Tukey's test at $5 \%$ probability (SISVAR version 5.6 ).

\section{RESULTS AND DISCUSSION}

Growth kinetics of $C$. sorokiniana cultured in different culture media are presented in Figure 1. The mixed medium presented two defined growth phases. The first phase occurred during the first 3-4 days of cultivation, followed by a short lag phase, before the second growth phase. This indicates that when glucose was exhausted from the medium (mixotrophic growth), the carbon source was replaced by $\mathrm{CO}_{2}$ (autotrophic growth). The mixotrophic growth has already been demonstrated in other studies, with higher growth rates compared to autotrophic and heterotrophic cultivations [26,27].

Cultures raised in the mixed medium had the maximum specific growth rate $\left(\mu_{\max }\right)$ among the evaluated media during the first growth phase (mixotrophic). It occurred due to the presence of glucose as a carbon source. The second growth phase (autotrophic) presented a decreased $\mu_{\max }$ (Table 1). Cells grew in Bold Basal and NPK media presents very 
close $\mu_{\max }$ values: 0.067 and 0.065 , respectively (Table 1 ). It indicates that NPK may be a good option for low-cost microalgae productions, despite the final cell concentration $\left(\mathrm{X}_{\max }\right)$ obtained with NPK was half of that achieved with Bold Basal (Table 1).

Table 1: Kinetic parameters of Chlorella sorokiniana growth in different media.

\begin{tabular}{|c|c|c|c|c|c|c|}
\hline Medium & $\mathrm{ABS}_{\max }$ & $\mu_{\max }\left(\right.$ day $\left.^{-1}\right)$ & DT (days) & $\mathrm{X}\left(\times 10^{6}\right.$ cell $\left.\mathrm{mL}^{-1}\right)$ & $P_{X}\left(\times 10^{5}\right.$ cell $L^{-1}$ day $\left.^{-1}\right)$ & T (days) \\
\hline Nitrogenated & $0.942 \pm 0.004^{\mathrm{b}}$ & $0.090 \pm 0.003^{b}$ & $7.8 \pm 0.4^{c}$ & $5.00 \pm 0.02^{b}$ & $1.73 \pm 0.01^{\mathrm{b}}$ & 27 \\
\hline NPK & $0.519 \pm 0.002^{\mathrm{e}}$ & $0.065 \pm 0.001^{\mathrm{c}}$ & $10.7 \pm 0.2^{\mathrm{b}}$ & $2.76 \pm 0.01^{\mathrm{e}}$ & $1.01 \pm 0.01^{\mathrm{d}}$ & 24 \\
\hline Bold basal & $0.849 \pm 0.003^{\mathrm{c}}$ & $0.067 \pm 0.002^{\mathrm{c}}$ & $10.3 \pm 0.4^{\mathrm{b}}$ & $4.51 \pm 0.02^{\mathrm{c}}$ & $1.55 \pm 0.01^{\mathrm{c}}$ & 27 \\
\hline Mixed (mixotrophic) & $0.542 \pm 0.002^{\mathrm{d}}$ & $0.94 \pm 0.00^{\mathrm{a}}$ & $0.7 \pm 0.0^{\mathrm{d}}$ & $2.88 \pm 0.01^{\mathrm{d}}$ & $8.50 \pm 0.05^{\mathrm{a}}$ & 3 \\
\hline Mixed (autotrophic) & $1.098 \pm 0.005^{\mathrm{a}}$ & $0.04 \pm 0.00^{\mathrm{d}}$ & $17.3 \pm 0.0^{\mathrm{a}}$ & $5.82 \pm 0.03^{\mathrm{a}}$ & $1.47 \pm 0.02^{\mathrm{c}}$ & $20 *$ \\
\hline
\end{tabular}

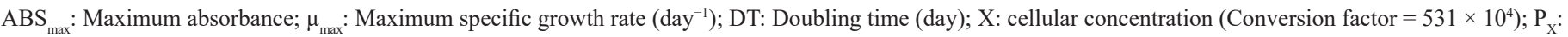
cell productivity; T: time to reach maximal cell content. All cultivations were carried out in triplicate and analysis in duplicate. Data presented as mean \pm standard deviation. Means followed by the same superscript in a column do not differ among themselves by the Tukey's test at $5 \%$ probability. $*$ Days after the mixotrophic phase $\left(23^{\text {th }}\right.$ day of cultivation).

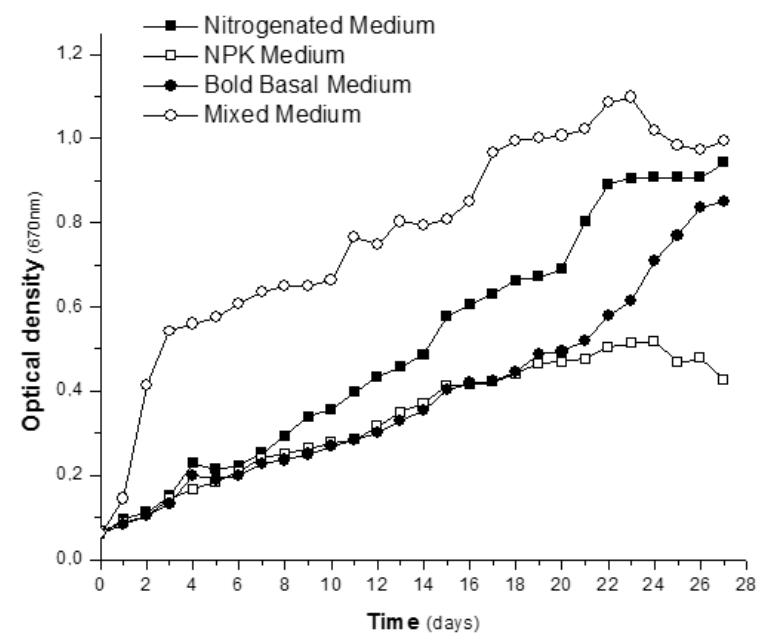

Figure 1: Growth kinetics of Chlorella sorokiniana in different culture media.

The mixotrophic action of $C$. sorokiniana was possible due to the photoperiod cycles, as the light availability is directly related to inorganic carbon consumption [28]. The growth of the microalgae cannot be considered equal to a conventional growth of bacteria and yeasts due to the autotrophic growth, since in this condition it presents a constant growth, without the differentiation of the phases of latency and logarithmic.

However, it is possible to observe the stationary and/or declining phases, as a result of nutrient depletion. The declining phase was observed after 23 days for mixed medium and after 24 days for NPK medium. Nitrogenated medium presented only the stationary phase after 22 days of cultivation, while growth was extended up to 27 days in Bold Basal medium (Figure 1). In this sense, Bold Basal medium can be considered here as the most complete medium in terms of nutrients, for autotrophic growth. The mixed medium, composed of $50 \%$ Bold Basal, 50\% NPK plus $1 \mathrm{~g} \mathrm{~L}^{-1}$ glucose, presented an intermediary behavior in terms of nutrient, which is explicated by the combination of two sources of nutrients: Bold Basal (richest) and NPK (poorest) media, and also by the high demand of nutrients for biomass synthesis, required mainly during the heterotrophic growth.

In this sense, we can affirm that, in general, there was a relation between the nature and concentrations of nutrients in the different media and microalgal growth, as the higher cell concentrations and cell productivities, despite we cannot discuss it compound by compound for each evaluated medium. This is an indication of how efficient the recovery of the nitrogen and phosphorus present in media was by concentrating these nutrients in algal biomass [29], which is important for the seed germination.

Nevertheless, in the germination study, it was observed that there was no significant difference between the treatments presented in Figure 2. The germination rate and the differences in the dry mass resulting from the weighing of the germinated seedlings are shown in Table 2.

Table 2: Germination and dry mass of lettuce seeds.

\begin{tabular}{ccc} 
Treatments & Germination $(\%)$ & Dry mass $(\mathbf{g})$ \\
Control & $36.0 \pm 19.0^{\mathrm{a}}$ & 0.1455 \\
Bold basal effluent & $48.0 \pm 8.0^{\mathrm{a}}$ & 0.1454 \\
Nitrogenated medium effluent & $43.0 \pm 12.8^{\mathrm{a}}$ & 0.1798 \\
NPK medium effluent & $46.0 \pm 11.5^{\mathrm{a}}$ & 0.1513 \\
Mixed medium effluent & $47.0 \pm 14.0^{\mathrm{a}}$ & 0.1798 \\
Microalgae* $2.70 \times 10^{7}$ & $40.0 \pm 5.7^{\mathrm{a}}$ & 0.1840 \\
Microalgae* $1.23 \times 10^{7}$ & $43.0 \pm 12.4^{\mathrm{a}}$ & 0.1760 \\
Microalgae* $0.15 \times 10^{7}$ & $43.0 \pm 10.0^{\mathrm{a}}$ & 0.1606 \\
\hline Coefficient of variation $^{7}$ & 28.38 & \\
\hline
\end{tabular}

Means followed by the same superscript in the column do not differ among themselves by the Tukey's test at $5 \%$ probability; * cells $\mathrm{mL}^{-1}$.

Considering that all the growth curves for $C$. sorokiniana obtained for each medium achieved the stationary phase from 23 to 27 days (Figure 1; Table 1), and that the germination of the seeds was evaluated with the 27 days cultured media, it is most probable that the nutrients were depleted from the media, at least the growth-limiting ones. In this sense, only cells could have interfered in seed germination, and the variables for that would be cell concentration and composition.

As observed, seed germination in the three treatments with different concentrations of $C$. sorokiniana, obtained from the same cultured Bold Basal medium did not differ significantly (Table 2). However, cell composition could have influenced seed germination. Each species of microalga is capable of producing different levels of biomass components [30] and has the ability to alter its metabolism according to the changes in the chemical composition of the culture medium and other culture conditions, including aeration, light intensity, temperature and age of the culture [31,32]. Here we did not evaluate algal cell composition in each treatment, but even if there were differences between them, the small number of cells used during germination experiments may not have been enough to reflect the results obtained. 


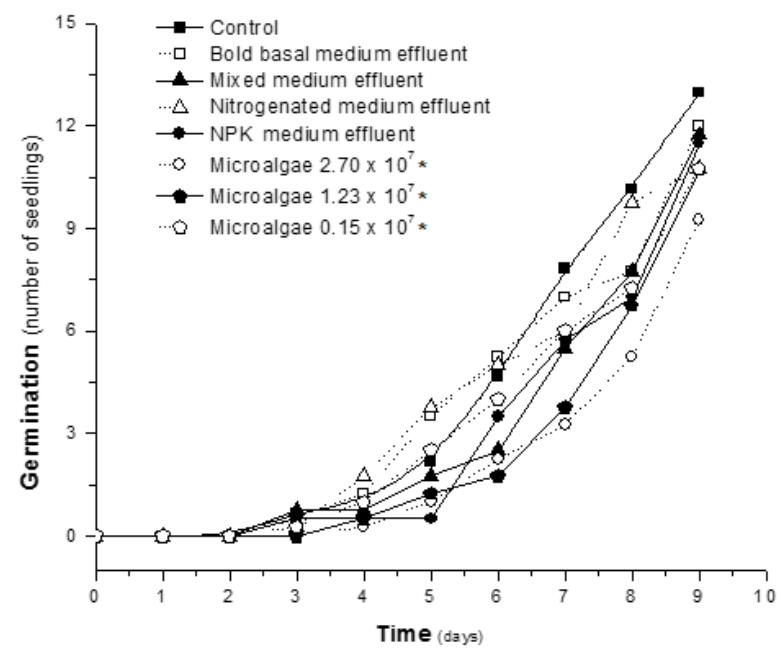

Figure 2: Germination kinetics of lettuce seeds in different culture media. *Bold Basal medium effluent with microalgae cell concentrations adjusted to $2.7 \times 10^{7}, 1.23 \times 10^{7}$ and $0.15 \times 10^{7}$ cells $\mathrm{mL}^{-1}$.

The organic fertilizer has greater effectiveness after the germination when it is in contact with the vegetal part. In the treatments where there was the use of the microalgae containing effluents as organic fertilizers obtained an increased dry mass. It tends to reflect in a higher vegetative growth, a superior productivity of the plants and possibility of seed generation with utmost physiological potential [33,34]. It was reported elsewhere that the microalgal fertilizers also increased the quality and economic value of horticulture products by increasing their carbohydrate and carotenoid contents [16].

Finally, the sensitivity of lettuce seeds produces an efficient response as a bioindicator of toxicity [13]. According to the obtained results neither microalgae containing effluent nor microalgae presented toxicity for germination. Germination is determined not only by the imbibed substance, but the whole condition prevailing during germination as all of them influence the metabolic activities of the seed [35].

\section{CONCLUSION}

The use of microalgae effluents as organic biofertilizers for plant development is an option for biotechnological applications. The experiments did not show differences in the germination rate in all treatments, but there was a dry mass gain of the germinated seedlings. This experiment can become a proposal for new production systems combining the microalgal cultivation with horticulture.

\section{ACKNOWLEDGMENTS}

The authors gratefully acknowledge the Brazilian research funding agencies CNPq, CAPES, and FUNDECT for their financial support.

\section{REFERENCES}

1. Stephenson PG, Moore CM, Terry MJ, Zubkov MV, Bibby TS, Improving photosynthesis for algal biofuels: toward a green revolution. Trends Biotechnol 2011; 29:615-623.

2. Richardson JW, Johnson MD. Financial feasibility analysis of NAABB developed technologies. Algal Res 2015; 10:16-24.

3. Harun R, Singh M, Forde GM, Danquah MK. Bioprocess engineering of microalgae to produce a variety of consumer products. Renew Sustain Energy Rev 2010; 14:1037-1047.
4. Mata TM, Martins AA, Caetano NS. Microalgae for biodiesel production and other applications: a review. Renew Sustain Energy Rev 2010; 14:217-232.

5. Foley PM, Beach ES, Zimmerman JB. Algae as a source of renewable chemicals: opportunities and challenges. Green Chem 2011; 13:13991405.

6. Draaisma RB, Barbosa MJ, Slegers PM, Brentner LB, Roy A, Wijffels RH. Food commodities from microalgae. Curr Opin Biotechnol 2013; 24:169-177.

7. Vanthoor-Koopmans M, Wijffels RH, Barbosa MJ, Eppink MHM. Biorefinery of microalgae for food and fuel. Bioresour Technol 2013; 135:142-149.

8. Koller M, Muhr A, Braunegg G. Microalgae as versatile cellular factories for valued products. Algal Res 2014; 6:52-63.

9. Granados MR, Acién FG, Gómez C, Fernández-Sevilla JM, Molina Grima E. Evaluation of flocculants for the recovery of freshwater microalgae. Bioresour Technol 2012; 118:102-110.

10. Halim R, Danquah MK, Webley PA. Extraction of oil from microalgae for biodiesel production: A review. Biotechnol Adv 2012; 30:709-732.

11. Borges L, Morón-Villarreyes JA, D’Oca MGM, Abreu PC. Effects of flocculants on lipid extraction and fatty acid composition of the microalgae Nannochloropsis oculata and Thalassiosira weissflogii. Biomass Bioenergy 2011; 35:4449-4454.

12. Barros AI, Gonçalves AL, Simões M, Pires JCM. Harvesting techniques applied to microalgae: A review. Renew Sustain Energy Rev 2015; 41:1489-1500.

13. Abdalla AMS, Bashir NHH, Assad YOH. Lactuca spp. seeds as a bioindicator for the toxicity of gezira tannery corporation wastewater. Jpn J Vet Res 2013; 61:S41-S43.

14. Diniz AA, Cavalcante LF, Rebequi AM, Nunes J, Brehm MAS. Liquid cattle manure and urea in soil on growth and biomass production of yellow passion fruit plants. Rev Ciên Agron 2011; 42:597-604.

15. Uysal O, Uysal FO, Ekinci K. Evaluation of microalgae as microbial fertilizer. Eur J Sustain Develop 2015; 4:77-82.

16. Coppens J, Grunert O, Van Den Hende S, Vanhoutte I, Boon N, Haesaert G, De Gelder L. The use of microalgae as a high-value organic slow-release fertilizer results in tomatoes with increased carotenoid and sugar levels. J Appl Phycol 2016; 28:2367-2377.

17. Tarakhovskaya ER, Maslov YI, Shishova MF. Phytohormones in algae. Rus J Plant Physiol 2007; 54:163-170.

18. Stirk WA, Bálint P, Tarkowská D, Novák O, Strnad M, Ördög V, van Staden J. Hormone profiles in microalgae: gibberellins and brassinosteroids. Plant Physiol Biochem 2013; 7:348-353.

19. Stirk WA, Ördög V, Novák O, Rolcík J, Strnad M, Bálint P, van Staden $\mathrm{J}$. Auxin and cytokinin relationships in twenty-four microalgae strains. J Phycol 2013; 49:459-467.

20. Pulz O, Gross W. Valuable products from biotechnology of microalgae. Appl Microbiol Biotechnol 2004; 65:635-648.

21. Bischoff HW, Bold HC. Phycological studies. IV. Some soil algae from enchanted rock and related algal species. University of Texas Publications 1963; 6318:1-95.

22. Dragone G, Fernandes B, Vicente AA, Teixeira JA. Nutrient limitation as a strategy for increasing starch accumulation in microalgae. Appl Energy 2011; 88:3331-3335.

23. Sipaúba-Tavares LH, Pelicione LC, Oliveira A. Use of an inorganic fertilizer (NPK) and the Chu12 medium for cultivation of Ankistrodesmus gracilis in the laboratory. Braz J Ecol 1999; 3:10-15.

24. Nascimento VM, Silva LF, Gomez JGC, Fonseca GG. Growth of Burkholderia sacchari LFM 101 cultivated in glucose, sucrose and glycerol. Scien Agric 2016; 73:429-433.

25. ISTA. 2008. International Seed Testing Association. Testing coated seeds. In: International rules for seed testing. ed. Bassersdorf. cap.11, p.11.1-11.8; annexe11, p.11A.1-11A.3.

26. Cheirsilp B, Torpee S. Enhanced growth and lipid production of microalgae under mixotrophic culture condition: Effect of light intensity, glucose concentration and fed-batch cultivation. Bioresour 
Technol 2012; 110:510-516.

27. Stemmler K, Massimi R, Kirkwood AE. Growth and fatty acid characterization of microalgae isolated from municipal waste-treatment systems and the potential role of algal-associated bacteria in feedstock production. Peer J 2016; 4:e1780.

28. Derner RB, Ohse S, Villela M, de Carvalho SM, Fett R. Microalgae, products and applications. Ciên Rural 2006; 36:1959-1967.

29. Cai T, Park SY, Li YB. Nutrient recovery from wastewater streams by microalgae: status and prospects. Renew Sust Energ Rev 2013; 19:360369 .

30. Behrens PW, Kyle DJ. Microalgae as a source of fatty acids. J Food Lipids 1996; 3:259-272.

31. Dunstan GA, Volkman JK, Barrett SM, Leroi J-M, Jeffrey SW. Essential polyunsaturated fatty acids from 14 species of diatom (Bacillariophyceae). Phytochemistry 1993; 35:155-161.

32. Guschina IA, Harwood JL. Lipids and lipid metabolism in eukaryotic algae. Prog Lipid Res 2006; 45:160-186.
33. Carvalho MAC, Arf O, Sá ME, Buzetti S, Santos NCB, Bassan DAZ. Bean (Phaseolus vulgaris L.) yield and seed quality under the influence of nitrogen split and sources. Rev Bras Ciên Solo 2001; 25:617-624.

34. Santos HC, Viana JS, Gonçalves EP, Bruno RLA, Fraga VS Physiological quality of sorghum seeds in response to copper and zinc fertilization. Rev Caatinga 2008; 21:64-74.

35. Logan DC, Millar AH, Sweetlove LJ, Hill SA, Leaver CJ. Mitochondrial biogenesis during germination in maize embryos. Plant Physiol 2001; 125:662-672.

How to cite this article:

Ribeiro DM, Zanetti GT, Julião MHM, Masetto TE, Gelinski JMLN, Fonseca GG. Effect of different culture media on growth of Chlorella sorokiniana and the influence of microalgal effluents on the germination of lettuce seeds. J App Biol Biotech. 2019;7(01):006-010. DOI: 10.7324/JABB.2019.70102 